\title{
Percutaneous Nephrolithotomy and Horseshoe Kidneys
}

\author{
Robin Bahadur Basnet ${ }^{l}$, Anil Shrestha ${ }^{1}$, Parash Mani Shrestha ${ }^{1}$, \\ Biswa Raj Joshi ${ }^{1}$ \\ ${ }^{1}$ Department of Urology, National Academy of Medical Sciences, Bir Hospital, Kathmandu, Nepal.
}

\section{ABSTRACT}

Introduction: The most common fusion anomaly, horseshoe kidney, is associated with vascular anomalies, malrotation, anterior displacement of the collecting system, superior insertion of ureter into the pelvis, and a higher rate of ureteropelvic junction obstruction; thus increasing the chances of nephrolithiasis. We present our experience with percutaneous nephrolithotomy in this anomaly.

Materials and Methods: A retrospective study of all the percutaneous nephrolithotomy performed by standard technique within four years at Bir Hospital was made. A comparison was made with similar cases with the anatomically normal location of the kidney. Intraoperative variables were recorded and postoperative stone-free status and complications were evaluated.

Results: Six hundred and twenty-seven patients out of 691 who had undergone percutaneous nephrolithotomy in this period were included. Patients with nephrolithiasis in horseshoe kidney were younger, the incidence of multiple stones was more; without full staghorn calculus and occupying fewer calyces. Upper pole access was easier, a stone clearance of $85.42 \%$ was achieved with no major complications in the horseshoe kidney.

\section{Correspondence:}

Dr. Robin Bahadur Basnet

Associate Professor and Head, Department of Urology National Academy of Medical Sciences, Bir Hospital ORCID ID: 0000-0001-9899-3095

Email: robinbasnet@gmail.com

Submitted: $23^{\text {rd }}$ November 2020 Accepted: $18^{\text {th }}$ December 2020

Source of Support: None Conflict of Interest: None

Citation: Basnet RB, Shrestha A, Shrestha PM, Joshi BR. Percutaneous nephrolithotomy and horseshoe kidneys. NMJ 2020;3(2):343-6. DOI $10.3126 / \mathrm{nmj}$ v3i2.33032

Conclusions: Percutaneous access and nephrolithotomy are safe in horseshoe kidney with a good stone clearance rate.

Keywords: Complications; Horseshoe kidney; Percutaneous nephrolithotomy; Stone clearance

\section{INTRODUCTION}

Horseshoe kidneys (HSK) occur due to the fusion of the lower poles of kidneys during embryogenesis, preventing them from the normal ascent. They have been reported in 1 in 400 to 800 cases. ${ }^{1,2}$ Due to failure to ascend; numerous anatomical anomalies occur including malrotation and anterior displacement of the collecting system, superior insertion of ureter into the pelvis, and a higher rate of ureteropelvic junction obstruction. ${ }^{3,4}$ Impaired drainage from the pelvis results in hydronephrosis, a higher rate of urinary tract infections and calculi., ${ }^{5-7}$

Among various methods of renal stone management, percutaneous nephrolithotomy (PCNL) is the accepted method ${ }^{8-10}$, with reported success rates of up to $98 \% .^{11,12}$ Most surgeons are cautious to subject anomalous kidneys to any type of surgery, particularly PCNL due to fear of vascular anomalies ${ }^{13}$, percutaneous access problems, higher incidence of complications, and a lower success rate. ${ }^{14}$ We present our experience with PCNL in horseshoe kidneys.

\section{MATERIALS AND METHODS}

After ethical clearance for the study from the institutional review board, an observational study of all patients who underwent PCNL at Bir hospital was undertaken from April 2015 to March 2019. Informed consent for the study was taken from all patients. 
All patients were assessed preoperatively and demographic parameters were recorded. In addition to routine investigations; CT urography, along with stone density measured in unenhanced film, was done for all the patients. PCNL was done under general or spinal anesthesia. All PCNL done in a prone position, Transpapillary puncture made under fluoroscopic guidance using 18 gauze two-part needle after retrograde opacification of the pelvicalyceal system via 6 French ureteral catheters were only included in the study. The tract dilatation and number were either by single-shot technique or serial telescopic dilatation and single or multiple tracts respectively. Nephroscopy was done with a 21 Fr rigid nephroscope. Large stones were fragmented with laser or pneumatic lithotripter. Small stones and fragments were removed either by continuous normal saline irrigation using an irrigating pump or removed with forceps. The exit strategy was total tubeless, tubeless, or standard.

Postoperatively, patients were managed with intravenous fluids, antibiotics, and analgesics, and discharged when clinically stable. The patients were routinely followed up until 4 weeks of operation. Any complications during this period were categorized according to the modified Clavien classification score for PCNL. ${ }^{15}$ In cases when patients had more than one complication, only the highest Clavien score was included. A final analysis was done for patients fulfilling all the inclusion criteria.

\section{RESULTS}

During the study period, a total of 691 PCNL were performed by three consultant urologists. Six hundred and twenty-seven patients fulfilled the inclusion criteria and 64 patients had to be excluded due to various reasons as shown in table 1 .

Table 1: Reason for exclusion from the study among patients undergoing PCNL during the study period

\begin{tabular}{ll}
\hline Total & $\mathbf{6 9 1}$ \\
\hline Fulfilling the inclusion criteria & 627 \\
\hline Excluded & 64 \\
\hline - Age below 14 years & 18 \\
- No preoperative CT scan available & 12 \\
- Bilateral procedures & 3 \\
- Supine position & 13 \\
- Conversion to open procedures & 2 \\
- Concurrent ureteral calculus treatment & 8 \\
- Lost to follow up within 4 weeks & 8 \\
\hline Non Horse Shoe Kidney & 579
\end{tabular}

Among the study cohort, 48 (7.66\%) PCNL were done in patients with HSK. Table 2 summarizes the characteristics of the two study populations. Patients with HSK were significantly younger than those with kidneys in normal position. They had a significantly more number of calyces involved and multiple stones. None of the HSK cohorts had full staghorn calculus.

Table 2: Characteristics of study population and stones

\begin{tabular}{llll}
\hline Variables & $\begin{array}{l}\text { Non Horse Shoe } \\
(\mathbf{n}=\mathbf{5 7 9} ; \mathbf{9 2 . 3 4} \%)\end{array}$ & $\begin{array}{l}\text { Horse Shoe } \\
(\mathbf{n}=\mathbf{4 8} ; \mathbf{7 . 6 6} \%)\end{array}$ & $\begin{array}{l}\text { Significance } \\
\text { P-value }\end{array}$ \\
\hline $\begin{array}{l}\text { Age } \\
(\text { Mean } \pm \text { SD) }\end{array}$ & $37.94 \pm 12.35$ & $27.75 \pm 16.82$ & $<0.0001$ \\
\hline $\begin{array}{l}\text { BMI } \\
(\text { Mean } \pm \text { SD) }\end{array}$ & $22.31 \pm 16.32$ & $25.22 \pm 17.10$ & 0.2373
\end{tabular}

\begin{tabular}{llll}
\hline Variables & $\begin{array}{l}\text { Non Horse Shoe } \\
(\mathbf{n}=\mathbf{5 7 9} ; \mathbf{9 2 . 3 4} \%)\end{array}$ & $\begin{array}{l}\text { Horse Shoe } \\
(\mathbf{n}=\mathbf{4 8} ; \mathbf{7 . 6 6 \%})\end{array}$ & $\begin{array}{l}\text { Significance } \\
\text { P-value }\end{array}$ \\
\hline Gender & $325(56.13 \%)$ & $32(66.67 \%)$ & 0.1568 \\
-Male (\%) & $254(43.87 \%)$ & $16(33.33 \%)$ & \\
-Female (\%) & $299(51.64 \%)$ & $21(43.75 \%)$ & 0.2937 \\
\hline $\begin{array}{l}\text { Laterality } \\
\text {-Left (\%) }\end{array}$ & $280(48.36 \%)$ & $27(56.25 \%)$ & \\
-Right (\%) & & & \\
\hline $\begin{array}{l}\text { Stone Burden } \\
\text { in mm2 (Mean } \\
\pm \text { SD) }\end{array}$ & $354.61 \pm 277.90$ & $286.53 \pm 146.96$ & 0.0940 \\
\hline $\begin{array}{l}\text { Number of } \\
\text { calyces involved } \\
\text { (Mean } \pm \text { SD) }\end{array}$ & $1.73 \pm 0.87$ & $1.16 \pm 0.08$ & $<0.0001$ \\
\hline $\begin{array}{l}\text { Stone Density } \\
\text { (HU) (Mean } \pm \text { SD) }\end{array}$ & $1096.96 \pm 358.35$ & 1131.87 & \pm \\
\hline $\begin{array}{l}\text { Solitary Stones } \\
\text { (\%) }\end{array}$ & $471(81.35 \%)$ & $13(27.08 \%)$ & $<0.0001$ \\
\hline $\begin{array}{l}\text { Full Staghorn } \\
\text { (\%) }\end{array}$ & $47(8.12 \%)$ & $0(0 \%)$ & 0.0403 \\
\hline $\begin{array}{l}\text { Partial Staghorn } \\
\text { (\%) }\end{array}$ & $155(26.77 \%)$ & $13(27.08 \%)$ & 0.9629 \\
\hline
\end{tabular}

The perioperative outcomes have been summarized in table 3 . The collecting system was approached in the entire horseshoe kidneys with a single puncture into the calyx, almost exclusively from the upper pole calyx. In the non-horseshoe group, the number of tracts ranged from one to three, while all the patients in the HSK group had a single tract. The total time in the non-horseshoe group ranged from 15 to 115 minutes and 20 to 100 minutes in the HSK group. The stone-free rate in our study population was $83.09 \%$, with $82.9 \%$ in non-horseshoe kidney patients and $85.42 \%$ of patients with HSK. A total of $28.87 \%$ in the study had some complications, with $165(28.5 \%)$ complications in the non-horseshoe kidney group and $16(33.33 \%)$ in the HSK group. The complications were similar in both groups. Five non-horseshoe kidney patients required angioembolisation for bleeding complications. According to modified Clavien-Dindo classification, complications that occurred in PCNL patients are decsribed in table 4 .

Table 3: Perioperative outcome among the patients undergoing PCNL

\begin{tabular}{llll}
\hline Variables & $\begin{array}{l}\text { Non Horse Shoe } \\
(\mathbf{n = 5 7 9 ;} \text { 92.34 \%) }\end{array}$ & $\begin{array}{l}\text { Horse Shoe } \\
(\mathbf{n = 4 8 ;} \text { 7.66\%) }\end{array}$ & $\begin{array}{l}\text { Significance } \\
\text { P-value }\end{array}$ \\
\hline $\begin{array}{l}\text { Calyceal Puncture } \\
\text { (single) }\end{array}$ & $471(81.39 \%)$ & $48(100.0 \%)$ & 0.0010 \\
- Upper & $84 / 471$ & $47 / 48$ & \\
- Middle & $245 / 471$ & $1 / 48$ & \\
- Lower & $142 / 471$ & 0 & \\
\hline Access time (min) & $3.12 \pm 1.23$ & $3.42 \pm 1.46$ & 0.1102 \\
\hline Multiple tracts & $108(18.91 \%)$ & $0(0 \%)$ & 0.0009 \\
\hline $\begin{array}{l}\text { Operative Time } \\
\text { (min) }\end{array}$ & $45.46 \pm 18.28$ & $49.58 \pm 32.85$ & 0.1654 \\
\hline Stone free & $480(82.90 \%)$ & $41(85.42 \%)$ & 0.6547 \\
\hline Complications & $165(28.50 \%)$ & $16(33.33 \%)$ & 0.4783 \\
\hline
\end{tabular}


Table 4: Description of complications among the study population

\begin{tabular}{lll}
\hline Variables & Non Horse Shoe $(\mathbf{n}=\mathbf{1 6 5} /)$ & Horse Shoe $(\mathbf{n}=\mathbf{1 6})$ \\
\hline Clavien 1 & $96(58.18 \%)$ & $7(43.75 \%)$ \\
\hline Clavien 2 & $32(19.39 \%)$ & $7(43.75 \%)$ \\
\hline Clavien 3a & $32(19.39 \%)$ & $2(12.50 \%)$ \\
\hline Clavien 3b & $5(3.03 \%)$ & - \\
\hline Clavien 4a & - & - \\
\hline Clavien 4b & - & - \\
\hline Clavien 5 & - & - \\
\hline
\end{tabular}

\section{DISCUSSION}

The horseshoe kidney represents the most common fusion anomaly of the kidneys. During weeks 4 to 6 of gestation, the metanephric blastema abnormally migrates across the midline. ${ }^{16}$ As the kidneys develop the inferior poles fuse, creating an isthmus, which can be a band of fibrous tissue or a thick rim of parenchyma. The isthmus prevents normal cranial migration,

because the renal ascent is arrested by the inferiormesenteric artery. ${ }^{13}$ Horseshoe kidney have been reported in 1 in 400 to 800 cases. ${ }^{1,2}$ We however had almost $7.7 \%$ of our study population with this anomaly. It could be attributed to a higher incidence of nephrolithiasis in horseshoe kidney and also due to referrals from other institutions into our tertiary level referral center.

Impaired drainage of the collecting system due to high insertion of ureter into pelvis and association with ureteropelvic junction obstruction resulting in stasis is the cause of infection, hydronephrosis, and nephrolithiasis. ${ }^{3-7}$ We noticed the occurrence of nephrolithiasis at a younger age compared to the normal population. There was no statistical difference in gender, body mass index, and laterality. We also noticed that although the number of calyces involved was fewer in horseshoe kidneys, with stones mostly in the pelvis, middle and lower calyces; multiple stones occurred more with the horseshoe kidney itself. There was no full staghorn calculus in the entire horseshoe kidney population.
The two main factors to be vigilant during percutaneous access in horseshoe kidneys are blood supply and orientation of the collecting system. Most blood vessels except some to the isthmus enter the kidney from its ventromedial aspects and the dorsal arteries to the isthmus are protected by the spine. Thus percutaneous access in a prone position, being from the opposite side, is safe. ${ }^{14}$ Inferior displacement of the kidney away from the pleura, dorsolateral or dorsomedial alignment of the calyces allow for a safe upper caliceal puncture, which will be more medial than that in normal kidneys. All, except one, access was through upper calyx and none required more than one tract. Upper pole access permits stone removal and inspection of all polar calyces, pelvis, and proximal ureter. As the pelvis may be deep in relation to the puncture site, an extra long amplatz sheath is recommended, ${ }^{14}$ but we did not encounter this difficulty may be because of the shorter stature of our population.

Different modalities have been used to manage stones in the horseshoe kidney, including open surgery, ESWL ${ }^{17,18}$ URS, $^{19,20}$ PCNL, and laparoscopy ${ }^{21,22}$. Open surgery has virtually been replaced by more minimally invasive techniques, with ESWL and PCNL being used in most patients ${ }^{13}$. Various works of literature have mentioned clearance of $22-80 \%$ clearance with extracorporeal shockwave lithotripsy (ESWL)..$^{13,17,18,23,24}$ We had a clearance rate of $85.42 \%$ in a single sitting, which is comparable to published studies. ${ }^{8-10}$ With auxiliary procedures i.e. relook PCNL, flexible ureterorenoscopic lithotripsy, or ESWL; stone clearance rate was $100 \%$ in horseshoe kidney. The ratios of complications in the two study $100 \%$ in horseshoe kidney population groups were similar. There were no bleeding complications in the horseshoe group that required angioembolisation, while five patients in the non-horseshoe population required angioembolisaiton. Vascular complications are fewer with horseshoe kidneys because commonly the stones are approached from the upper calyx and posteriorly whilst vascular supply is anterior and from lower poles and isthmus in horseshoe kidneys.

\section{CONCLUSIONS}

Although fraught with the danger of complications; percutaneous access and nephrolithotomy are safe in horseshoe kidneys with a good stone clearance rate.

\section{REFERENCES}

1. Kaufman E. Lehrbuch der speziellen pathologisten anatomie 2 Berlin; de Gryter 1957; pp. 427-36

2. Weizer AZ, Silverstein AD, Auge BK, Delvecchio FC, Raj G, Albala $\mathrm{DM}$, et al. Determining the incidence of horseshoe kidney from radiographic data at a single institution. J Urol. 2003;170(5):1722-6. $\underline{\text { Crossref }}$

3. Bellman GC, Yamaguchi R. Special considerations in endopyelotomy in a horseshoe kidney. Urology 1996;47:582-6. Crossref

4. Jabbour ME, Goldfischer ER, Stravodimos KG, Klima WJ, Smith AD. Endopyelotomy for horseshoe and ectopic kidneys. J Urol 1998;160:694-7. Crossref

5. Pawar AS, Thongprayoon C, Cheungpasitporn W, Sakhuja A, Mao MA, Erickson SB. Incidence and characteristics of kidney stones in patients with horseshoe kidney: A systematic review and meta- analysis. Urol Ann. 2018;10(1):87-93. Crossref

6. Evans WP, Resnik MI. Horseshoe kidney and urolithiasis. J Urol 1981;125:620-1. Crossref

7. Pitts WR, Muecke MI. Horseshoe kidney: A 40 years experience. J Urol 1975; 113: 743-6. Crossref

8. Al-Otaibi K, Hosking DH. Percutaneous stone removal in horseshoe kidneys. J Urol 1999;162:674-7. Crossref

9. Jones DJ, Wickham JE, Kellett MJ. Percutaneous nephrolithotomy for calculi in horseshoe kidneys. J Urol 1991;145: 481-3. Crossref

10. Raj GV, Auge BK, Weizer AZ, Denstedt JD, Watterson JD, Beiko DT, et al. Percutaneous management of calculi within horseshoe kidneys. J Urol 2003;170:48-51. Crossref 
11. Jones DJ, Russell GL, Kellett MJ, Wickham JE. The changing practice of percutaneous stone surgery. Review of 1000 cases 19811988. BJU Int 1990;66:1-5. Crossref

12. Segura JW, Patterson DE, Le Roy AJ, Williams HJ, Barrett DM, Benson RC, et al. Percutaneous removal of kidney stones: review of 1000 cases. J Urol 1985; 134: 1077-81. Crossref

13. Miller NL, Matlaga BR, Handa SE, Munch LC, Lingeman JE. The presence of horseshoe kidney does not affect the outcome of percutaneous nephrolithotomy. J Endourol. 2008;22(6):1219-25. Crossref

14. Razvi S, Zaidi Z. Percutaneous nephrolithotomy (PCNL) in horse shoe kidneys. J Pak Med Assoc. 2007;57(5):222-5. Website

15. de la Rosette JJ, Opondo D, Daels FP, Giusti G, Serrano A, Kandasami SV, et al. Categorisation of complications and validation of the Clavien score for percutaneous nephrolithotomy. Eur Urol 2012;62:246-255. Crossref

16. Hohenfellner M, Schultz-Lampel D, Lampel A, Steinbach F, Cramer BM, Thüroff JW. Tumor in the horseshoe kidney: Clinical implications and review of embryogenesis. J Urol 1992;147:1098-102. Crossref

17. Clayman RV. Effectiveness of extracorporeal shockwave lithotripsy in the management of stone-bearing horseshoe kidneys. J Urol 1998;160:1949. Website
18. Tunc L, Tokgoz H, Tan MO, Kupeli B, Karaoglan U, Bozkirli I. Stones in anomalous kidneys: Results of treatment by shock wave lithotripsy in 150 patients. Int J Urol 2004;11: 831-6. Crossref

19. Andreoni C, Portis AJ, Clayman RV. Retrograde renal pelvic access sheath to facilitate flexible ureteroscopic lithotripsy for the treatment of urolithiasis in a horseshoe kidney. J Urol 2000;164:1290-1. Website

20. Weizer AZ, Springhart WP, Ekeruo WO, Matlaga BR, Tan YH, Assimos DG, Preminger GM. Ureteroscopic management of renal calculi in anomalous kidneys. Urology 2005;65:265-9. Crossref

21. Valdivia-Uria JG, Abril Baquero G, Monzón Alebesque F, Alebesque F, López López JA, Lanchares Santamaría E. Laparoscopic management of complex lithiasis in horseshoe kidneys. (Spa) Actas Urol Esp 1994;18 (suppl):346-350. Website

22. Maheshwari PN, Bhandarkar DS, Shah RS, Andankar MG, Saple AL. Laparoscopy-assisted transperitoneal percutaneous nephrolithotomy for recurrent calculus in isthmic calix of horseshoe kidney. J Endourol 2004;18:858-861. Crossref

23. Serra AC, Moreno RP, Baron FR, Monreal Garcia de Vicuña F, Rousaud Barón A, Rodriguez JV. Current management of calculi in horseshoe kidneys. Scand J Urol Nephrol 200;34:114-8. Crossref

24. Kirkali Z, Esen AA, Mungan MU. Effectiveness of extracorporeal shockwave lithotripsy in the management of stone-bearing horseshoe kidneys. J Endourol 1996;10:13-5. $\underline{\text { Crossref }}$ 